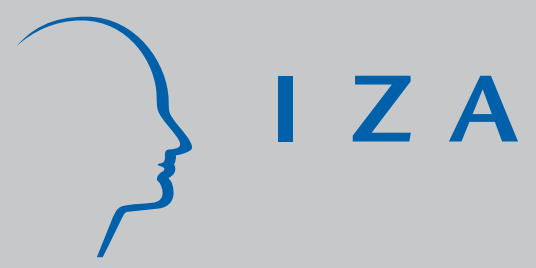

IZA DP No. 1259

Family Structure and Child Outcomes in the United States and Sweden

Anders Björklund

Donna K. Ginther

Marianne Sundström

August 2004 


\title{
Family Structure and Child Outcomes in the United States and Sweden
}

\author{
Anders Björklund \\ SOFI, Stockholm University \\ and IZA Bonn \\ Donna K. Ginther \\ University of Kansas \\ Marianne Sundström \\ SOFI, Stockholm University
}
Discussion Paper No. 1259
August 2004

IZA

P.O. Box 7240

53072 Bonn

Germany

Phone: +49-228-3894-0

Fax: +49-228-3894-180

Email: iza@iza.org

\begin{abstract}
Any opinions expressed here are those of the author(s) and not those of the institute. Research disseminated by IZA may include views on policy, but the institute itself takes no institutional policy positions.

The Institute for the Study of Labor (IZA) in Bonn is a local and virtual international research center and a place of communication between science, politics and business. IZA is an independent nonprofit company supported by Deutsche Post World Net. The center is associated with the University of Bonn and offers a stimulating research environment through its research networks, research support, and visitors and doctoral programs. IZA engages in (i) original and internationally competitive research in all fields of labor economics, (ii) development of policy concepts, and (iii) dissemination of research results and concepts to the interested public.
\end{abstract}

IZA Discussion Papers often represent preliminary work and are circulated to encourage discussion. Citation of such a paper should account for its provisional character. A revised version may be available directly from the author. 


\section{ABSTRACT \\ Family Structure and Child Outcomes in the United States and Sweden}

It is well known that children reared in non-intact families on average have less favorable educational outcomes than children reared in two-parent families. Evidence from the United States and Sweden indicates that living in a non-intact family is correlated with lower educational attainment. In this paper we compare the relationships between family structure and children's outcomes in terms of educational attainment and earnings using data from Sweden and the United States. Comparing the United States and Sweden is interesting because both family structure and public policy environments in the two countries differ significantly. Family structure could potentially have a less negative effect in Sweden than in the United States because of the extensive social safety net provided by that country. We find, however, the associations between family structure and children's outcomes to be remarkably similar in the United States and Sweden even though the policy and social environments differ between the two countries; living in a non-intact family is negatively related to child outcomes. This relationship is weakened when we control for other family characteristics, such as time lived with full and half siblings. In addition, when we use siblingdifference models to take account of unobserved family characteristics, the relationship is no longer statistically significant. Taken together, our results suggest that the true effect of family structure is more complex than the biological relationship of parents to children in both Sweden and the United States.

JEL Classification: J1, J12, 121

Keywords: family structure, parental separation, child welfare, educational attainment

Corresponding author:

Anders Björklund

SOFI

Stockholm University

10691 Stockholm

Sweden

Email: Anders.Bjorklund@sofi.su.se 


\section{Introduction}

It is well known that children reared in non-intact families on average have less favorable educational outcomes than children reared in two-parent families. For example, in the United States adults who were reared in single parent families are less likely to complete high school and attend college (Ginther and Pollak 2003). Studies from Sweden also report lower educational outcomes for adults who grew up in a non-intact family (Jonsson and Gähler 1997). However, studies of the effect of family structure on educational outcomes are complicated because the observed correlations could reflect the effects of unobserved variables that are correlated with both family structure and children's outcomes. These selection effects potentially bias the estimated effect of family structure on children's outcomes. In this paper we compare the effect of family structure on children's educational outcomes using data from Sweden and the United States.

Comparing Sweden and the United States is interesting because both family structure and public policy environments in the two countries differ significantly. Family structure could potentially have a less negative effect in Sweden than in the United States. First, social norms in Sweden have de-emphasized the importance of marriage as an institution. As a result, the stigma of growing up in a non-intact family may be less severe in Sweden than in the United States. Second, the extensive social safety net supporting families in Sweden may ameliorate the negative income shock to families when parents separate. For example, in Sweden parents receive a relatively generous child allowance and higher education is free, whereas in the United States support for parents with children is limited to income tax deductions or means-tested transfers for low-income families. To the extent that family income has an effect on children's educational outcomes, these different policy regimes could serve to magnify or ameliorate the impact of family structure. A comparison of the magnitude of family structure effects in Sweden and the United States allows us to determine whether public policy can soften the blow of family dissolution. We are aware of only one study that directly compares family structure in the United States and Sweden; Andersson 
(2002) examines the incidence of family disruption in 15 European countries and the U.S. He finds that fewer children are born to single mothers in Sweden than the U.S., but that more children are born outside of married unions (in consensual unions) in Sweden. Given these differences at birth, a remarkably similar number of children in the two countries experience a family disruption if they were born into a union. By age 15, 30 percent of children in Sweden and 40 percent of those in the U.S. had experienced some family disruption. The rates for the U.S. are the highest of all countries considered, and only two other European countries have higher rates of disruption than Sweden.

The data from Sweden are a random sample of individuals born in Sweden in 1964 through October 1965 drawn from the population registers of Statistics Sweden. These individuals are matched to their siblings and observed in the bidecennial censuses in 1965, 1970, 1975, and 1980. Educational and earnings outcomes are measured in 1996. The data from the United States are two samples taken from National Longitudinal Survey of Youth (NLSY--individuals living in the U.S. in 1979 and born between 1958 and 1965) and the Panel Study of Income Dynamics (PSIDindividuals living in the U.S. in 1968 and born between 1960 and 1970). Where possible, these individuals are matched to their siblings in the sample. Educational outcomes in both U.S. samples are measured between 1990 and 1994, while earnings are measured in 1993 for the PSID-sample and in 1994 for the NLSY-sample.

We use cross-section estimation to describe and examine the country differences in the correlations between family structure and children's outcomes. We exploit the panel structure of our data to construct measures of family structure that reflect the time children have spent in living in different family types, including time lived with full siblings and half siblings. In particular, we use the sibling structure of our data set to take account of unobserved family characteristics, which may influence child outcomes, by estimating family fixed-effect models. The outline of the remaining paper is as follows: Section 2 reviews previous studies in the U.S. and Sweden, Section 3 details the data and empirical approach, Section 4 presents the results, and Section 5 concludes. 


\section{Previous studies ${ }^{1}$}

\subsection{Family Structure and Child Outcomes in the United States}

McLanahan and Sandefur (1994) use four data sets to evaluate the relationship between family structure and children's outcomes. They find that high school graduation rates, college enrollment, and college graduation rates for children from single-parent and stepparent families are below those of children from two-parent families. Further, children from single-parent families tend to have higher rates of teen pregnancy and higher rates of economic inactivity than children from families with both biological parents. Biblarz and Raftery (1999) emphasize that empirical estimates of the influence of family structure on outcomes for children depend on the definitions of family structure groupings, which variables are controlled for, and the time period considered. After controlling for mother's employment and occupation, they find that children reared by a single mother have higher occupational status and educational attainment than children reared by a stepparent or single father.

Studies on blended families -- stepchildren and their half-siblings who are the biological children of both parents --in the United States have estimated the correlation between living with a stepparent and children's outcomes. Wojtkiewicz (1993) uses the National Longitudinal Survey of Youth to estimate the correlation between having a stepfather and children's schooling outcomes. He finds that duration of exposure to stepfather families reduces the probability of high school graduation. In more recent work, Wojtkiewicz (1998) examines the relationship between college entry and family structure and changes in family structure. Using data from the National Educational Longitudinal Survey, he defines stable family structures as those that do not change between 1988 and 1992. He finds that children from stable single-parent families are more likely to attend college than those from unstable single-parent families or stepchildren from blended

\footnotetext{
${ }^{1}$ In the following we review studies of family structure and child outcomes for the U.S. and Sweden; for studies for other countries, see, e.g., Ermisch and Francesconi (2001) for the U.K., Piketty (2003) for France and Winkelmann (2003) for Germany.
} 
families. Using data from the PSID, Boggess (1998) reports that stepchildren in stepfather families have lower rates of high school graduation than children growing up with both biological parents Ginther and Pollak (2003) find that educational outcomes for both types of children in blended families are similar to each other and substantially worse than outcomes for children reared in traditional nuclear families.

Studies that estimate the correlation between family structure and children's outcomes in most cases have found that living in a non-intact family is associated with lower educational attainment. Placing a causal interpretation on these results, however, is problematic because it involves assuming that there is no selection bias in the family structure estimates. Thus, Manski, Sandefur, McLanahan, and Powers (1992) evaluate the impact of identification assumptions about selection when estimating the effect of family structure on high school graduation. They demonstrate that the estimated effect of family structure depends on the assumptions imposed, concluding: "Any attempt to determine the family structure effect more tightly must bring to bear prior information about the process generating family structure and children's outcomes. As long as social scientists are heterogeneous in their beliefs about this process, their estimates of family structure may vary" (p. 36). Subsequent research bears out this conclusion.

Researchers have attempted to control for selection by using family fixed effects estimators. Under certain assumptions, controlling for the family fixed effect will eliminate this selection bias. Gennetian (2001) uses the NLSY-Child data to examine the effect of family structure on children's test scores and home environment. Controlling for unobserved heterogeneity across families and individuals, she finds that living in a single-mother family has a persistent negative effect on children's test scores although living with a stepparent or with half-siblings is no longer significant. Sandefur and Wells (1999) use a sample of siblings from the NLSY to estimate a multiple indicator, multiple cause model of educational attainment as a function of family structure. After controlling for unobserved family characteristics, they find that living outside of a two-parent family has a 
small, negative effect on educational attainment. Case, Lin and McLanahan (2001) use the PSID to evaluate the educational attainment of children living with their birth and non-birth mothers. They find after controlling for mother-fixed effects that children who live apart from the biological mothers have lower educational attainment. Finally, Evenhouse and Reilly (2001) use the National Longitudinal Study of Adolescent Health to evaluate children's well-being in blended families. Comparing siblings in blended families, they find that stepchildren fare worse in educational outcomes compared to their half-sibs. Some but not all of these results suggest that growing up in a single-parent family or as a stepchild in a blended family has a negative effect on children's schooling attainments.

Other researchers have used parental death as a quasi-natural experiment to examine the effect of family structure on children's educational outcomes, finding that family structure changes due to parental death have little impact on children's outcomes. Lang and Zagorsky (2001) use the National Longitudinal Survey of Youth (NLSY) to control for a wide variety of family background characteristics. They find that after controlling for parental absence due to death, family structure has little impact on the educational outcomes of their adult children. Biblarz and Gottainer (2000) compared children reared in single-mother families as a result of a father's death to children reared in divorced single-mother families. Children of divorced single mothers have lower educational attainment than those whose fathers have died.

In another identification approach, researchers have used instrumental variables to examine the effect of family structure on children's outcomes. Gruber (2000) employs 40 years of census data and changes in state divorce law to evaluate whether exposure to unilateral divorce is bad for children's educational outcomes. Gruber finds that on average, children from states exposed to unilateral divorce have lower educational outcomes. His analysis is estimated on data at the state level and cannot account for the effects of individual family characteristics on children's outcomes. Finally, researchers have compared children's educational outcomes before and after 
divorce. Cherlin et al. (1991) find that elementary school children whose parents eventually divorce performed poorly in school prior to the change in family structure. Painter and Levine (1999) investigate the extent to which the unfavorable outcomes for teenagers associated with non-marital birth, divorce, and remarriage are attributable to preexisting characteristics of the teenagers or the parents rather than to family structure. Using the National Educational Longitudinal Survey of 1988 (NELS), they find that the preexisting characteristics reported in the NELS fail to explain the differences in educational outcomes, and conclude that the association between family structure and outcomes for teenagers are causal.

It is clear from the above studies that living in a non-intact family is correlated with lower educational attainment in the United States. However, studies that attempt to control for the selection of family structure come to different conclusions depending on the identification assumptions employed.

\subsection{Family Structure and Child Outcomes in Sweden}

Studies of the association between family structure and children's educational outcomes in Sweden are fewer in number. Jonsson and Gähler (1997) use a large sample (about 120,000 cases) of persons born in 1972-76 to examine the correlation between family structure and the outcomes of early school-leaving and transition to upper-secondary school. They estimate cross-section equations as well as equations for change in family structure between 1985 and 1990. The crosssection estimates without control variables show that children from non-intact families have less favorable educational outcomes than those from intact-married families. When controls were added for household social class, household education, disposable income, number of siblings and house ownership these differences were substantially reduced. Thus, children who lived with a separated father or a separated mother and those who lived in a reconstituted family were less likely than those who came from intact-married families to continue school. However, there were no significant differences in this regard between children with married parents and those with 
cohabiting parents or widowed parents. They find similar associations between change in family structure and educational outcomes, especially transitions to upper-secondary school. For example, children whose parents divorced between 1985 and 1990 were less likely to continue to uppersecondary school than those whose parents remained married. They interpret the "effect" as causal and reflecting downward social mobility or economic deprivation, or both.

Björklund and Sundström (2002) analyze the association between parental separation and children's educational outcomes using a random sample of about 60,000 Swedes born in 1951-63 and their full siblings. Educational outcomes are measured by earnings-weighted education in 1996 . In line with Jonsson and Gähler (1997), the results of their cross-section estimation show that persons who a experienced a parental separation in childhood incur an educational disadvantage of about one year of schooling compared to those whose parents remained married or cohabiting. In contrast, in their family fixed-effects estimation, using only full siblings, they find that the effect of parental separation is not statistically significant. This suggests that the correlation between parental separation and children's educational outcomes reflect selection rather than causation.

\section{Data and empirical approach}

\subsection{Data}

\section{Data for the United States}

We use two U.S data sets and use the same schooling outcome variable in both data sets: Years of schooling, which we treat as a continuous variable. We also use log of annual earnings as a second outcome variable. The first sample is taken from the National Longitudinal Survey of Youth (NLSY). The NLSY began in 1979 with a nationally representative sample of 12,686 young adults between the ages of 14 and 21. Almost half of the observations in the NLSY $(5,863)$ come from multiple sibling households. To be included in our sample, individuals must have completed the 1988 Childhood Residence Calendar, have complete measures of schooling in at least one year 
between the 1990 and 1994 survey waves. Income is measured in 1994 . We eliminate individuals who are adopted, or report zero years of schooling, or report more than one change in family structure in a given year of childhood.

The second U.S. sample is taken from the Panel Study of Income Dynamics (PSID). The PSID began collecting data in 1968 on a nationally representative, longitudinal sample of 4800 households. Over time, as a result of births, marriages, divorces, and children leaving home, the PSID has followed individuals from their original families as new ones are formed. Our sample consists of individuals born between 1960 and 1970 with schooling outcomes observed between 1990 and 1993. Income is measured in 1993. In 1985 the PSID collected retrospective data providing information on the pair-wise relationship of all individuals in a 1968 family. We use this information from the 1968-85 Relationship file to derive our measures of family structure. We eliminate individuals who are not included in the 1968-85 Relationship file, who do not have a biological parent in the PSID sample, and who have no reported years of schooling.

\section{$\underline{\text { Data for Sweden }}$}

For Sweden we use a random sample of almost 36,000 (non-adopted) individuals born in Sweden in the years 1964 through October 1965 drawn from the population registers of Statistics Sweden. This sample is used in the descriptive section and the cross-section estimations. For the siblingdifference models, we match the random sample to their siblings born in 1960-1970 and observed in the bidecennial censuses in 1965, 1970 and 1975 (siblings born in 1960-1965), and in 1970, 1975 and 1980 (siblings born in 1966-1970). This is because we are interested in family structure only when they were children, i.e., below age 18 . The persons in the random sample were matched to nearly $35,000^{2}$ full siblings and almost 2,000 half siblings in the relevant age ranges. As we want siblings to have shared part of their early childhood, we require that all siblings (full and half) included in the analysis lived together with their random-sample sibling in the first census they

\footnotetext{
${ }^{2}$ The sample sizes are somewhat smaller in the analysis of earnings in 1996 since fewer persons had positive earnings.
} 
were observed, i.e., in 1965 and 1970, respectively. This requirement, however, results in most of the half siblings being on the mother's side and very few on the father's side (only about 190). Years of schooling in 1996 is measured as a continuous variable. The educational information has been obtained from Statistics Sweden's educational registers; we have inferred years of schooling from the information on highest level of education attained. Annual earnings are also measured in 1996 and include labor income plus sick pay and parental leave benefits. Our matched samples include about 61,000 full siblings and about 3,300 half siblings (fewer in the analysis of earnings).

\section{Measuring Family Structure}

At first blush, measurement of family structure is straightforward: Does a child live with one or both biological parents? However, this simple approach breaks down when one considers multiple sibling households and changes in family structure over time. In multiple sibling households, it is possible for one sibling to live with both biological parents, while the half-sibling lives with a biological parent and a stepparent. Measurement of family structure must take into account the complexity of parental and sibling relationships.

In addition, family structure can change over the childhood. For example, a child with a stepparent could potentially experience three separate family structures: living with both biological parents, living with a single parent, and living with a stepparent. Family structure measured at a child's particular age (age 14 in the NLSY) will not adequately capture the effect of these complex living arrangements. Most studies of the effect of family structure on child outcomes, including McLanahan and Sandefur (1994) and Manski et al. (1992), use one-year 'window' measurements taken at a given age as a proxy for family structure throughout childhood. ${ }^{3}$ Wolfe, Haveman, Ginther, and An (1996) examine the reliability of these 'window' variable estimates, conclude that one-year window variables serve as weak proxies for childhood circumstances and events, and can result in unreliable estimates.

\footnotetext{
${ }^{3}$ Wolfe, Haveman, Ginther, and An [1996] enumerate papers with the window problem.
} 
Family structure variables that are not subject to the 'window problem' can be created with retrospective data collected by the U. S. surveys and the Swedish Censuses. Using the data collected by the 1988 NLSY Childhood Residence Calendar Supplement, we construct age-specific changes in family structure over an individual's entire childhood, from ages zero to 16 . Using data collected in the 1968-85 PSID Family Relationship file, we construct age-specific changes in family structure over an individual's childhood ages one to 16. Using data from Sweden's bidecennial censuses, one can observe family structure from ages zero to 15 (for the matched siblings born in 1965 and in 1970 until age 10). The census data have the advantage of being less plagued by recall error and measurement error, but the disadvantage of not recording changes in family structure between censuses. In this analysis, family structure is characterized as the proportion of childhood that a child lives with both biological parents (regardless of whether they are formally married or cohabiting), with a single biological mother (single-mother), with a biological mother who is married to or cohabits with a stepfather (stepfather), with a single biological father (single-father), biological father who is married to or cohabits with a stepmother (stepmother) or alternative (other) family structures. ${ }^{4}$

\subsection{Samples}

We present the distribution of family structure for our two U.S. samples and the Swedish sample in Table 1a-c. We see that the two U.S. samples differ somewhat in the proportions never/always in an intact family and never/always with a biological mother and a stepfather. The difference in the U.S. samples results from the oversampling of low income households in the PSID; these individuals are more likely to have lived in non-intact families. The family structure of the Swedish

\footnotetext{
${ }^{4}$ In the United States samples to be considered a stepparent an individual must be married to the biological parent of the child. The proportion of childhood in a given family structure in the NLSY is measured as the number of years in that family structure divided by 17. In most cases an individual's childhood (ages 1-16) is not entirely observed between 1968 and 1985 in the PSID sample. Thus, we define family structure as the number of years a child between the ages of 1 and 16 is observed in the sample in a given family structure divided by the total number of years the child is ages 1-16 between 1968 and 1985. The proportion of childhood in a given family structure in Sweden is measured as the number of bidecennial censuses observed in that family structure divided by 4 in the descriptive section below and in the crosssection estimations but divided by 3 for the FE-estimations, see Section 3.1 Data for Sweden.
} 
sample, on the other hand, is rather similar to the one of the NLSY sample. For example, about 70 percent of children in both samples have lived in an intact family during their whole childhood and living with a single father or with a biological father plus stepmother are the least common family types in both samples. On the other hand, the fraction of children who spent the greater part of childhood with a single mother is larger in both U.S. samples than in the Swedish sample.

Table 1a: Percentages of U.S. NLSY sample $(\mathrm{N}=9,729)$ spending a proportion of childhood (P) in family types

\begin{tabular}{lrrrrrr}
\hline & Intact & $\begin{array}{r}\text { Single } \\
\text { mum }\end{array}$ & $\begin{array}{r}\text { Single } \\
\text { dad }\end{array}$ & $\begin{array}{r}\text { Biodad \& } \\
\text { stepmum }\end{array}$ & $\begin{array}{r}\text { Biomum \& } \\
\text { stepdad }\end{array}$ & Other type \\
\hline $\mathrm{P}=0$ & 7.2 & 73.9 & 97.1 & 97.8 & 90.2 & 94.6 \\
$0<\mathrm{P} \leq 1 / 4$ & 5.4 & 9.2 & 2.1 & 1.2 & 2.8 & 3.6 \\
$1 / 4<\mathrm{P} \leq 1 / 2$ & 6.8 & 6.2 & 0.6 & 0.6 & 2.9 & 0.8 \\
$1 / 2<\mathrm{P}<1$ & 13.3 & 7.2 & 0.3 & 0.5 & 3.9 & 1.0 \\
$\mathrm{P}=1$ & 67.3 & 3.5 & 0.0 & 0.0 & 0.3 & 0.0 \\
\hline
\end{tabular}

Notes: $\mathrm{P}=$ proportion of childhood. $\mathrm{P}=0$ indicates never living in a particular family structure; $\mathrm{P}=1$ indicates always living in a particular family structure. Intact $=$ Both biological parents, Single mum = Single unmarried mother, Single $\mathrm{dad}=$ Single unmarried father; Biodad $\&$ stepmum $=$ Stepmother married to biological father; Biomum $\&$ stepdad $=$ Stepfather married to biological mother; Other type = Other family structure-without a biological parent.

Table 1b: Percentages of U.S. PSID sample $(\mathrm{N}=2,308)$ spending a proportion of childhood (P) in family types

\begin{tabular}{lrrrrrr}
\hline & Intact & $\begin{array}{r}\text { Single } \\
\text { mum }\end{array}$ & $\begin{array}{r}\text { Single } \\
\text { dad }\end{array}$ & $\begin{array}{r}\text { Biodad \& } \\
\text { stepmum }\end{array}$ & $\begin{array}{r}\text { Biomum \& } \\
\text { stepdad }\end{array}$ & Other type \\
\hline $\mathrm{P}=0$ & 35.6 & 67.7 & 97.0 & 96.4 & 78.1 & 95.4 \\
$0<\mathrm{P} \leq 1 / 4$ & 1.3 & 5.6 & 1.1 & 0.8 & 4.7 & 2.1 \\
$1 / 4<\mathrm{P} \leq 1 / 2$ & 2.2 & 6.5 & 0.7 & 0.8 & 4.9 & 1.1 \\
$1 / 2<\mathrm{P}<1$ & 4.4 & 8.7 & 0.8 & 1.0 & 7.1 & 1.4 \\
$\mathrm{P}=1$ & 56.5 & 11.5 & 0.4 & 1.0 & 5.2 & 0.0 \\
\hline
\end{tabular}

Notes: see Table 1a.

Table 1c: Percentages of Swedish sample $(\mathrm{N}=35,911)$ spending a proportion of childhood $(\mathrm{P})$ in family types

\begin{tabular}{lrrrrrr}
\hline & Intact & $\begin{array}{r}\text { Single } \\
\text { mum }\end{array}$ & $\begin{array}{r}\text { Single } \\
\text { dad }\end{array}$ & $\begin{array}{r}\text { Biodad \& } \\
\text { stepmum }\end{array}$ & $\begin{array}{r}\text { Biomum \& } \\
\text { stepdad }\end{array}$ & \\
\hline $\mathrm{P}=0$ & 5.8 & 83.5 & 94.6 & 98.0 & 89.4 & 90.7 \\
$0<\mathrm{P} \leq 1 / 4$ & 5.2 & 10.0 & 4.2 & 1.5 & 5.0 & 7.2 \\
$1 / 4<\mathrm{P} \leq 1 / 2$ & 8.0 & 4.4 & 1.0 & 0.4 & 3.4 & 1.2 \\
$1 / 2<\mathrm{P}<1$ & 12.5 & 1.6 & 0.1 & 0.1 & 1.9 & 0.4 \\
$\mathrm{P}=1$ & 68.5 & 0.4 & 0.0 & 0.0 & 0.3 & 0.4 \\
\hline
\end{tabular}

Notes: see Table 1a. A stepparent is an adult in the household who is not a biological parent. 


\subsection{Average outcomes by family type in Sweden and the U.S.}

Next we compare the distribution of education and earnings in Sweden and the United States. We get an overview of the differences in child outcomes by family structure in the two countries by comparing average years of schooling and average annual earnings (indexed) by family structure in Table 2a-2c and Table $3 a-3 c$.

Table 2a: Average years of schooling by proportion of childhood (P) in family types. U.S. NLSY sample $(\mathbf{N}=\mathbf{9 , 7 2 9})$

\begin{tabular}{lrrrrrr}
\hline & Intact & $\begin{array}{r}\text { Single } \\
\text { mum }\end{array}$ & $\begin{array}{r}\text { Single } \\
\text { dad }\end{array}$ & $\begin{array}{r}\text { Biodad \& } \\
\text { stepmum }\end{array}$ & $\begin{array}{r}\text { Biomum \& } \\
\text { stepdad }\end{array}$ & \\
\hline $\mathrm{P}=0$ & 12.0 & 13.0 & 12.9 & 12.9 & 12.9 & 12.9 \\
$0<\mathrm{P} \leq 1 / 4$ & 12.2 & 12.5 & 12.6 & 12.4 & 12.2 & 11.4 \\
$1 / 4<\mathrm{P} \leq 1 / 2$ & 12.4 & 12.4 & 11.8 & 12.1 & 12.4 & 12.0 \\
$1 / 2<\mathrm{P}<1$ & 12.5 & 12.4 & 12.6 & 12.5 & 12.1 & 11.8 \\
$\mathrm{P}=1$ & 13.1 & 12.0 & $\mathrm{~N} / \mathrm{A}$ & $\mathrm{N} / \mathrm{A}$ & 12.4 & $\mathrm{~N} / \mathrm{A}$ \\
\hline
\end{tabular}

Note: A stepparent is an adult in the household who is not a biological parent and married to a biological parent.N/A = no observations in that cell.

Table 2b: Average years of schooling by proportion of childhood (P) in family types. U.S. PSID sample ( $\mathrm{N}=\mathbf{2 , 3 0 8})$

\begin{tabular}{lrrrccc}
\hline & Intact & $\begin{array}{r}\text { Single } \\
\text { mum }\end{array}$ & $\begin{array}{r}\text { Single } \\
\text { dad }\end{array}$ & $\begin{array}{r}\text { Biodad \& } \\
\text { stepmum }\end{array}$ & $\begin{array}{r}\text { Biomum \& } \\
\text { stepdad }\end{array}$ & Other type \\
\hline $\mathrm{P}=0$ & 12.4 & 13.1 & 12.9 & 12.9 & 13.0 & 12.9 \\
$0<\mathrm{P} \leq 1 / 4$ & 13.0 & 12.8 & 12.6 & 13.6 & 12.6 & 12.0 \\
$1 / 4<\mathrm{P} \leq 1 / 2$ & 13.0 & 12.5 & 12.3 & 12.7 & 12.8 & 12.4 \\
$1 / 2<\mathrm{P}<1$ & 12.6 & 12.6 & 13.1 & 12.3 & 12.6 & 12.7 \\
$\mathrm{P}=1$ & 13.2 & 12.2 & $12.1^{*}$ & $13.4^{*}$ & 12.4 & $12.0^{*}$ \\
\hline
\end{tabular}

Note: A stepparent is an adult in the household who is not a biological parent and married to a biological parent.

* Fewer than 20 observations.

Table 2c: Average years of schooling by proportion of childhood $(\mathrm{P})$ in family types. Swedish sample $(\mathrm{N}=35,911)$

\begin{tabular}{lrrrrrr}
\hline & Intact & $\begin{array}{r}\text { Single } \\
\text { mum }\end{array}$ & $\begin{array}{r}\text { Single } \\
\text { dad }\end{array}$ & $\begin{array}{r}\text { Biodad \& } \\
\text { stepmum }\end{array}$ & $\begin{array}{r}\text { Biomum \& } \\
\text { stepdad }\end{array}$ & \\
\hline $\mathrm{P}=0$ & 10.7 & 11.5 & 11.5 & 11.5 & 11.5 & 11.4 \\
$0<\mathrm{P} \leq 1 / 4$ & 10.9 & 11.0 & 11.0 & 11.3 & 11.0 & 11.0 \\
$1 / 4<\mathrm{P} \leq 1 / 2$ & 11.1 & 11.0 & 10.8 & 11.0 & 10.8 & 10.8 \\
$1 / 2<\mathrm{P}<1$ & 11.3 & 11.0 & 11.0 & 11.0 & 10.9 & 10.6 \\
$\mathrm{P}=1$ & 11.6 & 10.8 & $9.7^{*}$ & $12.9^{*}$ & 11.1 & 10.2 \\
\hline
\end{tabular}

Note: A stepparent is an adult in the household who is not a biological parent.

* Fewer than 20 observations.

Although average years of schooling is higher in the U.S. than in Sweden, the patterns of years of schooling by family structure in the two countries are very similar. Children who spent the 
whole childhood in an intact family have the highest level of schooling whereas those who spent a greater part of childhood living in an non-intact family have lower schooling attainment. In both countries children from intact families have almost one additional year of schooling compared to those who spend more than half of their childhood in non-intact family structures.

Table 3a: Average annual earnings in 1994 by proportion of childhood $(P)$ in family types. U.S. NLSY sample $(\mathbf{N}=6,196)$. (Intact $P=1=100)$

\begin{tabular}{lrrcccc}
\hline & Intact & $\begin{array}{r}\text { Single } \\
\text { mum }\end{array}$ & $\begin{array}{r}\text { Single } \\
\text { dad }\end{array}$ & $\begin{array}{r}\text { Biodad \& } \\
\text { stepmum }\end{array}$ & $\begin{array}{r}\text { Biomum \& } \\
\text { stepdad }\end{array}$ & \\
\hline $\mathrm{P}=0$ & 59.6 & 97.7 & 92.4 & 92.3 & 93.5 & 93.5 \\
$0<\mathrm{P} \leq 1 / 4$ & 78.1 & 82.2 & 80.3 & 85.2 & 76.9 & 57.5 \\
$1 / 4<\mathrm{P} \leq 1 / 2$ & 74.4 & 77.2 & 54.1 & 60.3 & 83.7 & 68.4 \\
$1 / 2<\mathrm{P}<1$ & 82.3 & 73.0 & 85.2 & 75.1 & 70.9 & 59.6 \\
$\mathrm{P}=1$ & 100.0 & 58.2 & N/A & N/A & 69.4 & N/A \\
\hline
\end{tabular}

Note: A stepparent is an adult in the household who is not a biological parent.

Table 3b: Average annual earnings in 1993 by proportion of childhood $(P)$ in family types. U.S. PSID sample $(\mathbf{N}=1,901)$. (Intact $P=1=100)$

\begin{tabular}{lrrcccc}
\hline & Intact & $\begin{array}{r}\text { Single } \\
\text { mum }\end{array}$ & $\begin{array}{r}\text { Single } \\
\text { dad }\end{array}$ & $\begin{array}{r}\text { Biodad \& } \\
\text { stepmum }\end{array}$ & $\begin{array}{r}\text { Biomum \& } \\
\text { stepdad }\end{array}$ & Other type \\
\hline $\mathrm{P}=0$ & 74.5 & 97.7 & 90.8 & 90.3 & 93.3 & 91.4 \\
$0<\mathrm{P} \leq 1 / 4$ & 77.4 & 95.5 & 75.2 & $141.9^{*}$ & 77.4 & 81.8 \\
$1 / 4<\mathrm{P} \leq 1 / 2$ & 108.3 & 69.5 & $71.0^{*}$ & $84.0^{*}$ & 77.6 & 52.2 \\
$1 / 2<\mathrm{P}<1$ & 79.6 & 73.1 & $103.0^{*}$ & 69.8 & 83.6 & 66.0 \\
$\mathrm{P}=1$ & 100.0 & 66.0 & $92.3^{*}$ & 107.3 & 81.3 & $\mathrm{~N} / \mathrm{A}$ \\
\hline
\end{tabular}

Note: A stepparent is an adult in the household who is not a biological parent.

* Fewer than 20 observations.

Table 3c: Average annual earnings in 1996 by proportion of childhood $(P)$ in family types. Swedish sample $(\mathbf{N}=35,911)$. (Intact $P=1=100)$

\begin{tabular}{lrrrccc}
\hline & Intact & $\begin{array}{r}\text { Single } \\
\text { mum }\end{array}$ & $\begin{array}{r}\text { Single } \\
\text { dad }\end{array}$ & $\begin{array}{r}\text { Biodad \& } \\
\text { stepmum }\end{array}$ & $\begin{array}{r}\text { Biomum \& } \\
\text { stepdad }\end{array}$ & Other type \\
\hline $\mathrm{P}=0$ & 85.5 & 92.2 & 97.7 & 97.1 & 98.2 & 97.7 \\
$0<\mathrm{P} \leq 1 / 4$ & 89.6 & 90.8 & 89.6 & 94.8 & 87.9 & 90.2 \\
$1 / 4<\mathrm{P} \leq 1 / 2$ & 90.1 & 89.5 & 91.3 & 93.1 & 89.0 & 83.8 \\
$1 / 2<\mathrm{P}<1$ & 94.2 & 88.4 & 90.1 & 100.0 & 90.1 & 77.5 \\
$\mathrm{P}=1$ & 100.0 & 82.1 & $74.6^{*}$ & $124.2^{*}$ & 91.9 & 81.5 \\
\hline
\end{tabular}

Note: A stepparent is an adult in the household who is not a biological parent.

* Fewer than 20 observations.

As expected, average annual earnings differ much more by childhood family type in the U.S. than in Sweden. However, in both countries, annual earnings in most cases are lower for those from non-intact families. This may simply be a reflection of the lower schooling attainment of children from non-intact families. 


\subsection{Empirical approach}

We start by using cross-sectional estimation assuming exogenous selection. Let us for simplicity consider a two-child family where investments in the human capital of one child are a function of family economic resources, observable parental characteristics (education), family environment (tastes, proxied by family structure), and the sibling composition of the household. For child $i$ in family $j$ consider the following human capital investment decision:

$$
H C_{i j}=\alpha S_{i j}+\beta F S_{i j}+\gamma W_{i j}+\delta X_{i j}+u_{i j}
$$

where $H C_{i j}$ measures a child's educational or earnings outcome, $S_{i j}$ measures the sibling composition of the household, $F S_{i j}$ measures the proportion of childhood with both biological parents, $W_{i j}$ observable parental characteristics, $X_{i j}$ measures individual characteristics, and $u_{i j}$ is the error term.

We can decompose the error term into three components: $u_{i j}=\varphi_{j}+\eta_{i}+v_{i j}$, where $\varphi_{j}$ is the family-specific component, $\eta_{i}$ is the individual-specific component, and $v_{i j}$ is random error. If $\varphi_{j}$ is correlated with family structure, then first differencing across siblings will eliminate selection bias, but if family structure is correlated with individual-specific error components, then selection remains a problem. By assuming that family structure only operates through a family fixed effect, $\varphi_{j}$, and that all family effects are sibling-invariant, $\mathrm{W}_{i j}=\mathrm{W}_{j}$, we first difference (1) with respect to siblings and estimate the following equation:

$$
\Delta H C=\alpha \Delta S+\beta \Delta F S+\delta \Delta X+\Delta u
$$

Under our assumptions, this model eliminates any observed or unobserved variables that do not vary within a family. The approach we take is to use cross sectional regressions to estimate versions of equation (1) with different control variables and then control for family fixed effects using equation (2). 


\section{Results}

\subsection{Cross-section estimations}

We start by estimating cross-section equations of the correlation between years of schooling and proportion of childhood spent in different family types, controlling for age and gender for the two countries. The resulting estimates are presented in Table 4a (coefficients on gender and age are omitted). Interestingly, we find strikingly similar relationships for the two countries, which is remarkable given the egalitarian educational policy and additional social support available to families in Sweden.

Table 4a: Regression of childhood family structure on educational attainment for Sweden and U.S. Samples. Dependent variable: Years of schooling.

\begin{tabular}{cccc}
\hline Education & Sweden & NLSY & PSID \\
\hline Single Mother & $-1.01^{*}$ & $-0.94^{*}$ & $-0.87^{*}$ \\
& $(0.07)$ & $(0.09)$ & $(0.12)$ \\
Single Father & $-1.51^{*}$ & $-1.27^{*}$ & -0.76 \\
& $(0.14)$ & $(0.41)$ & $(0.49)$ \\
Stepmother, biological father & -0.28 & $-0.96 \sim$ & -0.15 \\
& $(0.23)$ & $(0.43)$ & $(0.39)$ \\
Stepfather, biological mother & $-0.86^{*}$ & $-1.09^{*}$ & $-0.58^{*}$ \\
& $(0.07)$ & $(0.14)$ & $(0.17)$ \\
Other family structure & $-1.15^{*}$ & $-2.30^{*}$ & -0.80 \\
& $(0.09)$ & $(0.32)$ & $(0.58)$ \\
\# Observations & 35,911 & & \\
R-square & 0.022 & 0.033 & 2,308 \\
\hline
\end{tabular}

Sweden: controlling for age, age2, gender. U.S.: Controlling for year of birth and gender. Robust standard errors. $* \mathrm{p}<.01 ; \sim \mathrm{p}<.05$

Next, we supplement our family-structure covariates with measures of proportion of childhood lived with full siblings and with half siblings, respectively, while controlling for total number of full siblings and half siblings, regardless of whether the individual lived with them or not. We can only use the PSID-data in this analysis because the NLSY does not have complete information on the sibling composition of the household over the entire childhood. In addition, we control for the education of step or biological parents. We see that the differences in schooling outcomes between children from intact families and those from non-intact families are reduced when childhood sibling structure and parents' education are taken into account (Table 4b). Also, 
while there is a positive and non-significant relationship between proportion of childhood lived with full siblings and years of schooling for the U.S., the relationship is negative for Sweden, but the relationship for proportion lived with half siblings is negative for both countries. The associations between educational outcomes and total number of full siblings and half siblings are both negative, more so for full siblings.

Table 4b. Regression of childhood family and sibling structure on educational attainment for Sweden and U.S. Samples. Dependent variable: Years of schooling.

\begin{tabular}{|c|c|c|c|}
\hline Education & Sweden & NLSY & PSID \\
\hline \multirow[t]{2}{*}{ Single Mother } & $-0.87^{*}$ & $-0.51^{*}$ & -0.31 \\
\hline & $(0.06)$ & $(0.09)$ & $(0.18)$ \\
\hline \multirow[t]{2}{*}{ Single Father } & $-1.07^{*}$ & -0.65 & -0.25 \\
\hline & $(0.14)$ & $(0.38)$ & $(0.48)$ \\
\hline \multirow[t]{2}{*}{ Stepmother, biological father } & $-0.48 \sim$ & $-0.87 \sim$ & 0.10 \\
\hline & $(0.21)$ & $(0.39)$ & $(0.42)$ \\
\hline \multirow[t]{2}{*}{ Stepfather, biological mother } & $-0.65^{\star}$ & $-0.98^{*}$ & -0.30 \\
\hline & $(0.08)$ & $(0.13)$ & $(0.17)$ \\
\hline \multirow[t]{2}{*}{ Other family structure } & $-0.97^{*}$ & $-1.20^{*}$ & 0.02 \\
\hline & $(0.09)$ & $(0.31)$ & $(0.54)$ \\
\hline \multirow[t]{2}{*}{ Lived with full siblings } & $-0.09 \sim$ & & 0.15 \\
\hline & $(0.04)$ & & $(0.12)$ \\
\hline \multirow[t]{2}{*}{ Lived with half siblings } & $-0.30^{*}$ & & -0.44 \\
\hline & $(0.06)$ & & $(0.40)$ \\
\hline \multirow[t]{2}{*}{ \# Full siblings } & $-0.14^{*}$ & & $-0.18^{*}$ \\
\hline & $(0.01)$ & & $(0.02)$ \\
\hline \multirow[t]{2}{*}{ \# Half siblings } & $-0.10^{*}$ & & -0.10 \\
\hline & $(0.01)$ & & $(0.09)$ \\
\hline \multirow[t]{2}{*}{ Mother's Education } & $0.17^{*}$ & $0.17^{*}$ & $0.06^{*}$ \\
\hline & $(0.01)$ & $(0.01)$ & $(0.01)$ \\
\hline \multirow[t]{2}{*}{ Father's Education } & $0.18^{*}$ & $0.17^{*}$ & $0.05^{*}$ \\
\hline & $(0.00)$ & $(0.01)$ & $(0.01)$ \\
\hline \# Observations & 35,911 & 9,729 & 2,308 \\
\hline R-square & 0.19 & 0.243 & 0.134 \\
\hline
\end{tabular}

Sweden: controlling for year and month of birth, gender. U.S.: controlling for year of birth, gender, and indicators for missing parental schooling. Robust standard errors. $* \mathrm{p}<.01 ; \sim \mathrm{p}<.05$

Note: Parent's education is the education in 1970 of the (step/bio)parents the child lived with in 1975 for Sweden sample. Parent's education is education of biological parent in U.S. samples.

We go on to estimate a similar set of cross-section equations of the correlation between (the log of) annual earnings and proportion of childhood spent in different family types, controlling for age and gender for the two countries. The resulting estimates are presented in Table 5a (coefficients on gender and age are omitted) and show that these relationships are also highly similar for the two 
Table 5a: Regressions of childhood family structure on annual earnings for Sweden and U.S. Samples. Dependent variable: Log of annual earnings.

\begin{tabular}{lccc}
\hline Earnings & Sweden & NLSY & PSID \\
\hline Single Mother & $-0.30^{*}$ & $-0.31^{*}$ & $-0.51^{*}$ \\
Single Father & $(0.03)$ & $(0.05)$ & $(0.09)$ \\
& $-0.46^{*}$ & $-0.48 \sim$ & 0.06 \\
Stepmother, biological father & $(0.08)$ & $(0.25)$ & $(0.24)$ \\
& $-0.13^{*}$ & $-0.60 \sim$ & -0.18 \\
Stepfather, biological mother & $(0.11)$ & $(0.25)$ & $(0.20)$ \\
& $-0.17^{*}$ & $-0.37^{*}$ & -0.10 \\
Other family structure & $(0.04)$ & $(0.10)$ & $(0.09)$ \\
& $-0.36^{*}$ & $-0.77^{*}$ & -0.22 \\
\# Observations & $(0.05)$ & $(0.19)$ & $(0.26)$ \\
R-square & 35,911 & 6,196 & 1,901 \\
Swed & 0.05 & 0.072 & 0.097 \\
\hline
\end{tabular}

Sweden: Controlling for year and month of birth, gender. U.S.: Controlling for year of birth, gender. Robust standard errors. ${ }^{*} \mathrm{p}<.01 ; \sim \mathrm{p}<.05$

countries. When we add controls for sibling structure and parents' education (Table 5b) the difference between children from intact families and those from other family types are reduced. In addition, sibling structure matters for earnings in both samples. In the PSID, there are negative associations between earnings and number of full siblings as well as the proportion of childhood spent with half siblings. For Sweden, earnings are negatively related to the number of both full siblings and half siblings. These results indicate that larger families may have fewer resources to invest in children's human capital accumulation. Furthermore, sibling structure is relatively more important in determining children's outcomes than family structure.

\subsection{Family fixed-effect models}

Table 6a presents fixed effect estimates of the relationship between family structure and educational attainment for the samples from the U.S. and Sweden. For Sweden the sample size is large enough to allow comparisons of this relationship also for half siblings who have the same mother. Whereas the family structure variables are negatively and significantly correlated with years of schooling in Table 4a, controlling for unobserved family heterogeneity the family-structure 
Table 5b. Regressions of childhood family and siblings structure on annual earnings for Sweden. Dependent variable: Log annual earnings.

\begin{tabular}{cccc}
\hline Earnings & Sweden & NLSY & PSID \\
\hline Single Mother & $-0.26^{*}$ & $-0.22^{*}$ & $-0.30^{*}$ \\
Single Father & $(0.04)$ & $(0.06)$ & $(0.11)$ \\
& $-0.40^{*}$ & -0.41 & 0.24 \\
Stepmother, biological father & $(0.08)$ & $(0.24)$ & $(0.25)$ \\
& -0.11 & $-0.55 \sim$ & -0.06 \\
Stepfather, biological mother & $(0.11)$ & $(0.25)$ & $(0.19)$ \\
& $-0.10 \sim$ & $-0.34^{*}$ & -0.03 \\
Other family structure & $(0.04)$ & $(0.10)$ & $(0.10)$ \\
& $-0.30^{*}$ & $-0.51^{*}$ & 0.01 \\
Lived with full siblings & $(0.05)$ & $(0.18)$ & $(0.27)$ \\
& 0.02 & & 0.03 \\
Lived with half siblings & $(0.02)$ & & $(0.07)$ \\
& -0.05 & & $-0.64 \sim$ \\
\# Full siblings & $(0.03)$ & & $(0.26)$ \\
& $-0.04^{*}$ & & $-0.06^{*}$ \\
\# Half siblings & $(0.01)$ & & $(0.01)$ \\
& $-0.03^{*}$ & & -0.03 \\
Mother's Education & $(0.01)$ & & $(0.04)$ \\
& $0.02^{*}$ & $0.02^{*}$ & $0.03^{*}$ \\
Father's Education & $(0.00)$ & $(0.01)$ & $(0.01)$ \\
& $0.01^{*}$ & $0.03^{*}$ & 0.01 \\
\# Observations & $(0.00)$ & $(0.004)$ & $(0.01)$ \\
R-squared & 35,911 & 6,196 & 1,901 \\
& 0.063 & 0.104 & 0.132 \\
\hline
\end{tabular}

Sweden: controlling for year and month of birth, gender. U.S.: controlling for year of birth, gender, and indicators for missing parental schooling. Robust standard errors. $* \mathrm{p}<.01 ; \sim \mathrm{p}<.05$

Note: Parent's education is the education in 1970 of the (step/bio)parents the child lived with in 1975 in Sweden sample. Parent's education is education of biological parent in U.S. samples.

coefficients were no longer statistically significant in either the United States or Sweden, neither fro full, nor for half siblings. Table $6 \mathrm{~b}$ shows fixed effects estimates of the impact of family structure on earnings. Controlling for unobserved heterogeneity reduces the magnitude of the family structure coefficients and they are no longer statistically significant. The one exception is the effect of living with a stepmother and biological father on earnings in the NLSY. After controlling for unobservable family characteristics spending one's childhood with a stepmother has a negative and significant effect on earnings. 
Table 6a. FE-estimates of the relationships between childhood family structure and educational attainment for Sweden and U.S. Dependent variable: Years of schooling.

\begin{tabular}{ccccc}
\hline & \multicolumn{3}{c}{ Sweden } & U.S. \\
\hline Education & Full sibl & Half sib m NLSY & PSID \\
\hline Single Mother & -0.05 & -0.47 & 0.11 & -0.14 \\
& $(0.20)$ & $(0.49)$ & $(0.20)$ & $(0.38)$ \\
Single Father & -0.14 & -0.08 & 1.25 & -0.96 \\
& $(0.28)$ & $(0.66)$ & $(1.16)$ & $(0.82)$ \\
Stepmother, biological father & -0.22 & -0.59 & -0.59 & 0.78 \\
& $(0.55)$ & $(2.18)$ & $(0.72)$ & $(0.62)$ \\
Stepfather, biological mother & 0.27 & -0.15 & -0.04 & 0.01 \\
& $(0.27)$ & $(0.16)$ & $(0.29)$ & $(0.30)$ \\
Other family structure & 0.06 & -0.19 & -0.49 & 0.77 \\
& $(0.27)$ & $(0.37)$ & $(0.62)$ & $(0.71)$ \\
Did not live w. sibling & -0.03 & -0.37 & & \\
& $(0.21)$ & $(0.48)$ & & \\
\# Groups & & & & \\
\# Observations & 26,453 & 1,475 & 1,976 & 659 \\
R-sq within & 60,944 & 3,146 & 4,679 & 1,718 \\
& 0.014 & 0.012 & 0.017 & 0.022 \\
\hline
\end{tabular}

Sweden: controlling for age, age2, gender. ${ }^{a}$ For full and half siblings who did not live with their sibling in the random sample we cannot classify family structure otherwise. Robust standard errors. ${ }^{*} \mathrm{p}<.01 ; \sim \mathrm{p}<.05$

Table 6b: FE-estimates of the relationships between childhood family structure and annual earnings for Sweden and U.S. Samples. Dependent variable: Log of annual earnings.

\begin{tabular}{|c|c|c|c|c|}
\hline \multirow[b]{2}{*}{ Earnings } & \multicolumn{2}{|c|}{ Sweden } & \multicolumn{2}{|c|}{ U.S. } \\
\hline & Full sib & $\begin{array}{l}\text { Half sib } \\
\text { mum }\end{array}$ & NLSY & PSID \\
\hline \multirow[t]{2}{*}{ Single Mother } & -0.11 & 0.36 & 0.18 & -0.14 \\
\hline & $(0.15)$ & $(0.49)$ & $(0.20)$ & $(0.34)$ \\
\hline \multirow[t]{2}{*}{ Single Father } & 0.31 & 0.10 & -0.08 & 0.26 \\
\hline & $(0.23)$ & $(0.72)$ & $(1.02)$ & $(0.68)$ \\
\hline \multirow[t]{2}{*}{ Stepmother, biological father } & -0.31 & -1.54 & $-1.52 \sim$ & 0.61 \\
\hline & $(0.40)$ & $(1.73)$ & $(0.59)$ & $(0.49)$ \\
\hline \multirow[t]{2}{*}{ Stepfather, biological mother } & 0.05 & 0.01 & -0.08 & 0.18 \\
\hline & $(0.21)$ & $(0.13)$ & $(0.24)$ & $(0.26)$ \\
\hline \multirow[t]{2}{*}{ Other family structure } & -0.34 & 0.15 & 0.04 & 0.22 \\
\hline & $(0.21)$ & $(0.40)$ & $(0.64)$ & (0.63) \\
\hline \multirow[t]{2}{*}{ Did not live w. sibling ${ }^{a}$} & 0.06 & -0.20 & & \\
\hline & $(0.18)$ & $(0.43)$ & & \\
\hline \# Groups & 24,484 & 1,263 & 1,670 & 639 \\
\hline \# Observations & 55,852 & 2,673 & 3,136 & 1,402 \\
\hline R-square within & 0.064 & 0.042 & 0.074 & 0.063 \\
\hline
\end{tabular}

Sweden: controlling for age, age 2 , gender. ${ }^{\mathrm{a}}$ For full and half siblings who did not live with their sibling in the random sample we cannot classify family structure otherwise. Robust standard errors $* \mathrm{p}<.01 ; \sim \mathrm{p}<.05$ 


\section{Conclusions}

We began this analysis expecting to find substantial differences between the United States and Sweden in the association between family structure and outcomes as adults, measured as educational attainment and annual earnings. We found strikingly similar educational differences by family structure in the two countries, whereas average earnings differentials by childhood family type were smaller in Sweden. While this is as expected, it may suggest that differences in wage formation systems are be more important than differences in educational policy in shaping the income distribution. When only family structure, age, and sex are included in the regression, nearly all non-intact family structure variables are negatively associated with years of schooling and annual earnings. However, when sibling composition and parents' education are included in the model, the estimated coefficients for family structure are reduced. In particular, our findings show that the number of full and half siblings, and the time lived with them, tend to be negatively related to educational attainment and earnings as adult in both countries.

Finally, controlling for unobserved family characteristics, we find that the effect of family structure in the both the Sweden and U.S. samples (in all but one case) becomes statistically insignificant. Taken together, our results suggest that the true effect of family structure is more complex than the biological relationship of parents to children in both Sweden and the United States. 


\section{REFERENCES}

Andersson, Gunnar. 2002. "Children's Experience of Family Disruption and Family Formation: Evidence from 16 FFS Countries.” Demographic Research, Vol. 7, No. 7. Available at http://www.demographic-research.org.

Behrman, Jere R., Mark R. Rosenzweig, and Paul Taubman. 1994. "Endowments and the Allocation of Schooling in the Family and the Marriage Market: The Twins Experiment," Journal of Political Economy, Vol. 102, No. 6, 1131-1174.

Biblarz, Timothy J., and Adrian E. Raftery. 1999. "Family Structure, Educational Attainment, and Socioeconomic Success: Rethinking the 'Pathology of Matriarchy"' American Journal of Sociology, Vol. 105, No. 2, 321-65.

Biblarz, Timothy J., and Greg Gottainer. 2000. "Family Structure and Children's Success: A Comparison of Widowed and Divorced Single-Mother Families,"' Journal of Marriage and Family, Vol. 62.

Björklund, Anders and Marianne Sundström. 2002. "Parental Separation and Children's Educational Attainment: A Siblings Approach.” Discussion Paper No. 643, IZA, Bonn.

Boggess, Scott. 1998. "Family Structure, Economic Status, and Educational Attainment," The Journal of Population Economics, Vol. 11, No. 2, 205-222.

Case, Anne, I-Fen Lin, and Sara McLanahan. 2001. "Educational Attainment of Siblings in Stepfamilies." Evolution and Human Behavior, Vol. 22, No. 4, 269-289.

Cherlin, Andrew J., Frank F. Furstenberg, P. Lindsay Chase-Lansdale, Kathleen E. Kiernan, et al., 1991. "Longitudinal Studies of Effects of Divorce on Children in Great Britain and the United States," Science, Vol. 252 No. 5011, 1386-89.

Ermisch, John F. and Marco Francesconi. 2001 "Family Structure and Children's Achievements," Journal of Population Economics, Vol. 14, No. 2, 249-270.

Evenhouse, Eirik, and Siobhan Reilly. 2001. "Selection Bias or Differential Treatment? Exploring Stepchildren's Poor Outcomes," mimeo, Mills College.

Evenhouse, Eirik, and Siobhan Reilly. 1997. "Divorce Laws and Divorce Rates: Evidence from Panel Data," mimeo, Mills College.

Gennetian, Lisa. 2001. "One or Two Parents? Half or Step Siblings? The Effect of Family Composition on Young Children." Mimeo, MDRC.

Ginther, Donna K. and Robert A. Pollak. 2003. "Does Family Structure Affect Children's Educational Outcomes?” NBER Working Paper 9628.

Gruber, Jonathan, "Is Making Divorce Easier Bad for Children? The Long Run Implications of Unilateral Divorce." 2000. National Bureau of Economic Research Working Paper 7968. 
Jonsson, Jan O. and Michael Gähler. 1997. "Family Dissolution, Family Reconstitution, and Children's Educational Careers: Recent Evidence from Sweden." Demography 34: 277-293.

Lang, Kevin, and Jay L. Zagorsky, "Does Growing Up With a Parent Absent Really Hurt?" Journal of Human Resources, Vol. 36, No. 2, (Spring 2001), 253-273.

McLanahan, Sara and Gary Sandefur, Growing Up with a Single Parent: What Hurts, What Helps, Cambridge: Harvard University Press, 1994.

Manski, Charles, Gary Sandefur, Sara McLanahan, and Daniel Powers. 1992. "Alternative Estimates of the Effect of Family Structure During Adolescence on High School Graduation," Journal of the American Statistical Association, Vol. 87 No. 417, 25-37.

Painter, Gary and David I. Levine, "Family Structure and Youths' Outcomes: Which Correlations Are Causal?” 2000. Journal of Human Resources, Vol. 35, No. 3, 524-549.

Piketty, Thomas. (2003). The impact of divorce on school performance. Evidence from France, 1968-2002, CEPR Discussion Paper 4146.

Winkelmann, Rainer. (2003). Parental separation and well-being of youths. IZA Discussion paper No. 894, Bonn: IZA.

Wojtkiewicz, Roger A. 1993. "Simplicity and Complexity in the Effects of Parental Structure on High School Graduation,” Demography, Vol. 30, No. 4, 701-717.

Wojtkiewicz, Roger A. 1998. "The Effects of Single and Stepparent Families on College Entry: Who Gets Hurt the Most?," mimeo, Louisiana State University. 